Maurice A. Deane School of Law at Hofstra University Scholarly Commons at Hofstra Law

Hofstra Law Faculty Scholarship

2008

\title{
Tales of Two Regimes for Regulating Limited Liability Law Firms in the U.S. and Australia: Client Protection and Risk Management Lessons
}

Susan Saab Fortney

Maurice A. Deane School of Law at Hofstra University

Follow this and additional works at: https://scholarlycommons.law.hofstra.edu/faculty_scholarship

\section{Recommended Citation}

Susan Saab Fortney, Tales of Two Regimes for Regulating Limited Liability Law Firms in the U.S. and Australia: Client Protection and Risk Management Lessons, 11 Legal Ethics 230 (2008)

Available at: https://scholarlycommons.law.hofstra.edu/faculty_scholarship/239

This Article is brought to you for free and open access by Scholarly Commons at Hofstra Law. It has been accepted for inclusion in Hofstra Law Faculty Scholarship by an authorized administrator of Scholarly Commons at Hofstra Law. For more information, please contact lawcls@hofstra.edu. 


\title{
Tales of Two Regimes for Regulating Limited Liability Law Firms in the US and Australia: Client Protection and Risk Management Lessons
}

\author{
SUSAN SAAB FORTNEY*
}

The expression "all for one, one for all" describes the perspective of lawyers practising in traditional law partnerships. The model no longer fits thousands of lawyers practising in limited liability firms in which firm principals do not share personal liability.

Since the birth of the limited liability partnership (LLP) structure in the United States in 1992, the limited liability firm has evolved as a popular organisational structure for United States lawyers practising in large law firms. ${ }^{1}$ Indeed, "the attractiveness of this option appears to increase in relation to a firm's size, and for law firms with more than fifty lawyers, the LLP is the most popular associational choice". ${ }^{2}$ Within a decade, Australian legislation in New South Wales expanded organisational choices to include incorporated legal practices (ILPs). As explained below, the legislation in New South Wales and other Australian jurisdictions, similar to limited liability legislation in the United States, provides a vicarious liability shield for firm lawyers.

Beyond this similarity in liability protection, the approaches used in Australia and in the US differ radically. From the standpoint of consumer protection, major differences emerge. The first difference relates to the fact that incorporated firms in Australia may sell stock to non-lawyers. This feature of the Australian scheme captured worldwide attention when Slater \& Gordon, a prominent plaintiffs' firm, raised A $\$ 35$ million, or US $\$ 29$ million, in its initial public offering on 21 May $2007 .{ }^{3}$ Skeptics criticised the commercialisation of law practice, questioning how firm lawyers could balance their duties to their investor-shareholders and their duties to their clients. ${ }^{4}$

The commentaries that oppose allowing non-lawyer shareholders often do not address two important public protection features of the Australian legislation. First, as in other

* Paul Whitfield Horn Professor, Texas Tech University School of Law, I thank Dr Christine Parker for her inspiration and assistance, Suzanne LaMire Le Mire for her helpful editing, and Christopher Jones for serving as my research assistant.

1 Robert W. Hillman, "Organizational Choices of Professional Service Firms: An Empirical Study" (2003) 58 Business Lamyer 1387, 1394.

2 Ibid, 1395.

${ }^{3}$ Lindsay Fortado, "Pressure on Law Firms to Sell Stakes to Public; British May Soon Follow Australian Lead" Bloomberg News (New York), 14 June 2007, Finance 16.

${ }^{4}$ See eg Carolyn Batt, "Law Firm's Float Raises Cash and Eyebrows" The Western Australian (Perth), 14 April 2007 , Finance 70 , quoting legal practitioners and a corporate law professor. 
Commonwealth countries, Australian jurisdictions require that lawyers carry professional liability insurance to protect persons injured by the acts and omissions of practising lawyers. The second consumer protection feature is unique. In Australia, incorporated firms must demonstrate that they have appropriate management controls in place to ensure that all legal services are provided in accordance with professional conduct obligations. To determine whether firms have fulfilled this responsibility, Australian regulators possess the authority to audit firm practices.

Before undertaking practice audits, Australian regulators have implemented a program requiring that incorporated firms conduct self-examination of firm practices, procedures and systems. Although the self-examination programs are still in their early stages, data already suggest that the regulatory initiative has contributed to a reduction in complaints against lawyers in firms that have completed the self-assessment process. Lawyers interested in improving the delivery of legal services and reducing their disciplinary and malpractice exposure should take note of these empirical findings.

To illuminate the differences in the Australian and US approach, Part I of this article reviews the genesis of limited liability firms in the US, considering holes in the regulatory regime that affect consumers and injured persons. With this background, Part II discusses consumer protection concerns related to eliminating general liability for professional firms. Part III examines possible negative consequences of allowing lawyers to practice in limited liability firms. Understanding these risks, Part IV turns to the Australian regulatory scheme, examining how the Australian approach addresses public protection issues related to law practice in incorporated firms. By learning about the Australian experience, lawyers around the world can better understand how auditing firm procedures, practices and culture can operate as the first step in raising the "ethics consciousness" within firms, and improving the delivery of legal services.

\section{Genesis of Limited Liability Firms in the US}

A brief overview of lawyers' attempts to limit their liability provides the backdrop for evaluating internal and external control of those organisations and impact on consumer protection. In the United States, lawyers' push to incorporate their practices stemmed from their desire to reap tax advantages available to shareholders in business corporations. Specifically, lawyers wanted to make tax-attractive contributions to retirement plans. ${ }^{5}$ Asserting that they should be able to participate in plans on the same basis as owners of business corporations, lawyers and other professionals obtained legislation allowing them to form professional corporations.

Although lawyers' initial interest in the corporate form was driven by tax issues, lawyers' concern about vicarious liability for the conduct of other firm agents evolved to be the dominant reason that lawyers incorporated. Long after changes in the US tax code eliminated many of the tax advantages for shareholders, lawyers continued to incorporate their practices in an effort to limit their personal liability. 
In 1988, the Internal Revenue Service issued a public revenue ruling concluding that a limited liability company (LLC) with limited liability and centralised management under Wyoming law would be classified as a partnership for federal tax purposes. ${ }^{6}$ Following this ruling, attorneys and business groups faced little opposition when they lobbied for the enactment of LLC legislation because "state legislators willingly traded off limited liability in hope of luring new businesses that might otherwise migrate to states with LLC legislation". ${ }^{7}$ Many states adopted legislation that explicitly authorised professionals to practice as LLCs, while some implicitly authorised professionals to use the LLC form by providing that LLCs could be organised for "any lawful purpose". 8

As the LLC form was spreading throughout the country, many professionals preferred to practise as partnerships, rather than having to organise and operate as an LLC or professional corporation. Multi-million dollar claims brought by the US government agencies following the savings and loan debacle spurred lawyers and accountants to rethink the established tenet that partners in general partnerships must share unlimited liability.

One group of lawyers who monitored the government's claims against lawyers pondered changing state law to allow partners in professional partnerships to limit their vicarious liability. ${ }^{9}$ In what may appear to have been an incredibly naive comment, a senior litigation partner asked why partners in general partnerships had to share unlimited liability for claims arising out of the conduct of firm agents. ${ }^{10}$ This suggestion provided the springboard for the professionals and sympathetic legislators to tackle changing state law.

Eventually legislation was drafted:

(1) extending the liability limitation to all partnerships;

(2) denying protection to partners for misconduct of those working under their supervision or direction;

(3) requiring an annual registration with the state and including of "LLP" or "registered limited liability partnership", in the firm name; and

(4) requiring liability insurance in an arbitrary and admittedly often inadequate amount of $\$ 100,000 .^{11}$

The bill was "quietly attached" to an omnibus bill "that authorised limited liability companies and included significant amendments to existing corporation and partnership statutes". ${ }^{12}$ Sections of the omnibus act amended and added provisions to the Texas Uniform Partnership Act to create a new type of partnership, a registered limited liability partnership. ${ }^{13}$

${ }^{6}$ Rev. Rul. 88-76, 1988-2 CB 360; later this rule was deemed "obsolete": 98 Rev. Rul 93-37; 1998-2 CB 133; for historical background on the evolution of the LLC form see Carol R. Goforth, "The Rise of the Limited Liability Company: Evidence of a Race between the States, but Heading Where?" (1995) 45 Syracuse Law Review 1193.

Karen C. Burke, "The Uncertain Future of Limited Liability Companies" (1995) 12 American Journal of Tax Policy 13, 20-21.

${ }^{8}$ Dirk G. Christensen and Scott F. Bertschi, "LLC Statutes: Use by Attorneys" (1995) 29 Georgia Lam Reviem $693,695-6$.

${ }^{9}$ Robert W. Hamilton, "Registered Limited Liability Partnerships: Present at the Birth (Nearly)" (1995) 66 University of Colorado Lam Reviem 1065, 1073.

10 Telephone Interview with Jack McCutchin, Partner of Crenshaw Dupree and Milam, LLP (26 November 2008).

11 Ibid.

12 Hamilton, supra n. 9, 1074.

${ }^{13}$ Steven A. Waters and Matthew D. Goetz, "Annual Survey of Texas Law: Partnerships" (1992) 45 Southwestern Law Fournal 2011, 2022. 
Within a relatively short period of time, the LLP form had swept throughout the US. The specific statutory prerequisites and liability shield varied from jurisdiction to jurisdiction. Initially, states followed the Texas model, adopting LLP legislation that only eliminated vicarious liability for tort claims. Within a few years, virtually all states adopted legislation providing partners with full protection against vicarious liability for all obligations of the firm. ${ }^{14}$

The public protection features also varied from state to state. The Texas statute conditions the liability shield on the firm maintaining at least US\$100,000 in liability insurance or providing evidence of financial responsibility. ${ }^{15}$ Some states recognise that US $\$ 100,000$ may be inadequate to cover defense costs and losses. These jurisdictions use firm size to determine the insurance requirement. ${ }^{16}$ In some states, court rules condition the liability shield on the law firm maintaining a minimum level of liability insurance. ${ }^{17}$ Surprisingly, many jurisdictions do not require that LLPs maintain even a modest level of liability insurance.

States also adopted different provisions related to the LLP notifying third parties as to the LLP status. The majority use the minimalist approach of simply requiring that references to the LLP include the initials, LLP, in the name, or the phrase "limited liability partnership". ${ }^{18}$

In considering whether practice in LLPs ran afoul of lawyers' professional rules of conduct, the American Bar Association (ABA) Standing Committee on Ethics and Professional Responsibility (ABA Ethics Committee) opined on whether, consistent with the ABA Model Rules of Professional Conduct (Model Rules), lawyers may practise in limited liability firms. In a formal ethics opinion, the ABA Ethics Committee concluded that the limitation on liability provided by the LLP structure does not violate the Model Rules. ${ }^{19}$ On the issue of communicating the LLP statutes to clients and third parties, the ABA Committee split on the issue of whether it was sufficient for lawyers to use only the initials "LLP" or the phrase "registered limited liability partnership". The ABA Committee's majority believed that the use of abbreviations "places clients on notice that their lawyer is practicing in a particular business form, and encourages them to inquire if they are in doubt as to its implications for them". The minority expressed concern "that the use of initials, without more, is not sufficient to make the limitation of liability apparent to the client". ${ }^{20}$ Empirical data I collected in a survey of business people reflected the concern that lay people do not know the effect of lawyers practising in limited liability firms. ${ }^{21}$

The Wisconsin Supreme Court apparently agreed that the use of initials or words does not adequately inform clients as to the effect of a firm operating as a limited liability firm. A Wisconsin Supreme Court Rule of Professional Conduct allows attorneys to practise in

${ }^{14}$ Robert W. Hamilton et al, Business Organizations (vol. 19 Texas Practice Series) (St Paul, MN, West, 2nd edn, 2008) $\$ 12.1$, noting that LLP statutes in a substantial majority of states now allow partners to limit their liability for all types of partnership obligations.

15 Vernon's Annotated Revised Civil Statutes of the State of Texas, art. 6132b-3.08 (West, 2008).

${ }^{16}$ For example, 211 CMR $\$ 24.04$ (West, 2008).

${ }^{17}$ Eg ILCS S Ct Rule 722 (West, 2008).

18 Alan R. Bromberg and Larry E. Ribstein, Bromberg and Ribstein on Limited Liability Partnerships, the Revised Uniform Partnership Act, and the Uniform Limited Partnership Act (2001) (New York, Aspen, 2008 edn, 2007), \$2.05.

${ }_{19}$ ABA Committee on Ethics and Professional Responsibility, Formal Op. 96-401 (1996) (ABA Ethics Opinion).

$20 \mathrm{Ibid}$.

21 Susan Saab Fortney, "Professional Responsibility and Liability Issues Related to Limited Liability Law Partnerships” (1998) 39 South Texas Lam Reviem 399, 414-16. 
limited liability organisations, provided that the organisation gives public notice, as well as actual notice to clients. In addition to requiring a written designation of the limited liability structure as part of its name, the firm must also "provide to clients and potential clients in writing a plain-English summary of the features of the limited liability law under which the firm organized". 22

This Wisconsin Supreme Court Rule that goes beyond legislative requirements for limited liability firms illustrates how the judiciary exercises its inherent authority to regulate the legal profession. Regardless of legislative enactments, the highest court in a state in the US may take the position that the court, not the legislature, has the final word in determining whether lawyers may practice in limited liability firms. ${ }^{23}$ For example, for many years after the adoption of LLP legislation in Illinois, the Illinois Supreme Court declined to allow lawyers to practise in limited liability firms. Eventually, in 2005, the Illinois Supreme Court adopted a rule allowing lawyers to practise in limited liability firms provided that they satisfy various requirements, such as maintaining insurance.

In short, a review of the patchwork of limited liability legislation in the US reveals that the consumer protection features are like liability-limited at best. With the exception of states, such as California, that require a meaningful level of insurance, persons injured by conduct of lawyers in limited liability firms may be left seeking recovery from individual tortfeasors and thinly capitalised firms. The following section examines risk externalisation and other negative consequences of allowing professionals to practise in limited liability firms.

\section{Agency Issues and Public Policy Concerns Related to Practice in Limited Liability Firms}

Economists have characterised the structure of law firms as a nexus of contracts between owners of factors of production and customers. These contracts specify agents' rights, performance criteria, and payoffs. ${ }^{24}$ Professionals in firms, such as attorney-agents, offer inalienable human capital and perform services for client-principals in exchange for a residual claim against the firm's net cash flow. ${ }^{25}$

Monitoring by firm agents can be used to lower agency costs. First, monitoring minimises the risk that a partner will shirk and take a free ride on the efforts of other agents. ${ }^{26}$ Monitoring also improves the quality of legal services, controls liability losses, and enhances the human capital of the partners. ${ }^{27}$ In this sense, monitoring protects both clients and firm

${ }^{22}$ Wis S Ct Rule 20:5:7 (West, 2008); the Wisconsin Supreme Court declined to use the approach advanced by the Wisconsin State Bar, which would have allowed firms simply to use abbreviations to communicate their limited liability structure; Clay R. Williams, "LLCs, LLPs and SCs: The Rules for Lawyers Have Changed" Wisconsin Lamyer, May 1997, 10, 61 \& n. 17.

${ }^{23}$ Charles W. Wolfram, "Inherent Powers in the Crucible of Lawyer Self-Protection: Reflections on the LLP Campaign" (1998) 39 South Texas Lam Reviem 359, 373-81.

${ }^{24}$ Eugene F. Fama and Michael C. Jensen, "Separation of Ownership and Control" (1983) 26 Journal of Lam E Economics 301, 302.

${ }^{25}$ Eugene F. Fama and Michael C. Jensen, "Agency Problems and Residual Claims" (1983) 26 Journal of Law E Economics 327, 346-7.

${ }^{26}$ Ronald J. Gilson and Robert H. Mnookin, "Sharing Among the Human Capitalists: An Economic Inquiry into the Corporate Law Firm and How Partners Split Profits" (1985) 37 Stanford Law Review 313, 380-1.

${ }^{27}$ Fama and Jensen, supra n. 25, 335. 
owners from the consequences of malfeasant agents when controls prevent negligent or other wrongful conduct. If misconduct injures a client or a third person, unlimited liability of partners also improves the likelihood of recovery for damages when the assets of the firm and the wrongdoer fail to cover the costs of the misconduct.

Both tort principles and economics theory recognise the value of imposing vicarious liability on owners of professional firms. Tort law allocates risk to the principal as a cost of doing business through agents because the principal, rather than the injured tort victim, stands in the best position "to distribute [the risks], through prices, rates of liability insurance, to the public, and so to shift them to society". ${ }^{28}$ This in turn creates an incentive for principals to carefully select, instruct and supervise personnel and to take "every precaution" to see that they conduct the enterprise safely. ${ }^{29}$

Beyond risk allocation, various scholars have also asserted that imposing liability deters harmful conduct by encouraging precautions in the delivery of professional services. First, the risk of individual tort liability discourages individual lawyers from engaging in tortious activity. Second, the risk of enterprise liability should motivate the firm managers to monitor individual lawyers. ${ }^{30}$ Finally, the risk of facing vicarious liability for the acts of one's partners encourages partners to devote time and resources to monitoring and risk management activities that promise to reduce their personal liability exposure. ${ }^{31}$

Conversion to a limited liability firm undercuts these incentives in two ways. First, it eliminates unlimited liability as an economic incentive to devote time and resources to monitoring the conduct of firm players. ${ }^{32}$ Second, lawyers may avoid managerial and supervisory roles and even assisting other lawyers because such activities may subject the lawyer to personal liability for the acts of others. In their treatise on LLPs, Professors Larry Ribstein and Alan Bromberg describe the perverse effects as follows:

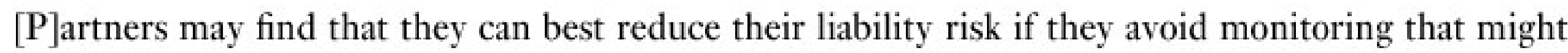
trigger liability for participating in misconduct under a negligence theory or under statutory language that focuses liability on direct supervisors or partners who have notice or knowledge of misconduct. For example, specialists may refuse to learn about cases in which they are not directly involved, and firms may abolish opinion committees. This may hurt both firms and their clients. ${ }^{33}$

Those limited liability statutes that impose supervisory liability exasperate this risk and actually create a disincentive, undermining partners' willingness to participate in firm management and supervisory activities. As a partner with no vicarious liability exposure, why should one get involved in firm management and supervision if those precise activities expose one's personal assets? Is the desire to protect the firm's reputation and assets enough to risk personal liability exposure? ${ }^{34}$

${ }^{28}$ W. Page Keeton et al, Prosser and Keeton on The Law of Torts (St Paul, MN, Hornbook Series, 5 th edn, 1984) $\S 69,500-01$.

$29 \mathrm{Ibid}, 501$.

30 Jeffrey A. Parness, "The New Federal Rule 11: Different Sanctions, Second Thoughts" (1995) 83 Illinois Business Journal 126, 129.

${ }^{31}$ Fama and Jensen, supra n. 25, 335.

${ }^{32}$ Martin C. McWilliams, Jr, "Who Bears the Costs of Lawyers' Mistakes?-Against Limited Liability" (2004) 36 Arizona State Law Journal 885, 917.

${ }^{33}$ Bromberg \& Ribstein, supra n. 18, §3.04(b), 128 (citations omitted).

${ }^{34}$ Scott Baker and Kimberly D. Krawiec, "The Economics of Limited Liability: An Empirical Study of New York Law Firms" [2005] University of Illinois Law Reviem 107. 
Eliminating vicarious liability also allows firm partners to externalise the costs of doing business when firm and individual tortfeasors' assets fall short of the amount necessary to satisfy tort claims. Rather than requiring those persons who benefit from economic activity to bear the losses incurred as a result of misconduct by a firm actor, limited liability allows firms to shift to others some of the costs of doing business. ${ }^{35}$

The recent dissolution of Jenkens \& Gilchrist illustrates how partners may benefit from risky behaviour of individual firm partners and not bear all the costs of the activity. Jenkens \& Gilchrist, a Texas-based firm, moved into Chicago when three tax lawyers joined the firm. ${ }^{36}$ These lawyers opined on risky tax shelter investments. ${ }^{37}$ In connection with this tax shelter work, the firm reportedly earned over US\$267 million in fees. ${ }^{38}$ After the Internal Revenue Service (IRS) disallowed hundreds of millions in tax benefits to investors, the firms faced various malpractice claims, including a class action which reputedly settled for US $\$ 81.55$ million, with the firm paying US\$5.25 million and the insurers and other defendants paying the remainder. ${ }^{39}$ The firm also faced a US\$76 million penalty that the IRS assessed for "promotion of abusive and fraudulent tax shelters and violation of the tax law concerning tax shelter registration and maintenance and turnover to the IRS of tax shelter investor lists". ${ }^{40}$ The firm eventually closed its doors.

Had the firm been organised as a general partnership, all firm partners could have been jointly and severally liable for losses. Such personal liability may have created an incentive for partners to monitor the conduct of firm principals closely. Unlimited liability may also have contributed to firm principals sticking with the firm rather than jumping ship. In this sense, limited liability can contribute to lawyer mobility and asset insufficiency.

The risk of shifting liability to injured persons increases when firms are thinly capitalised. ${ }^{41}$ Other than accounts receivable and malpractice insurance proceeds, firms may not hold significant assets subject to execution following a judgment. Lenders and large contract creditors may require security interests in accounts receivable and hard assets. Sophisticated persons who deal with limited liability firms and professional corporations may require that firm members sign personal guarantees. When faced with tort liability for some members and contract liability guaranteed by all members, firm members would likely give priority to paying the contract liability guaranteed by all firm owners. This may leave tort victims with an unsatisfied judgment against the firm and the individual tortfeasors.

When non-torfeasing members make contributions to the firm, they fund firm liabilities. Understanding this possibility, members may distribute firm revenues and minimise investments in the firm as a way of reducing their exposure for tort damages. In this sense, limited liability actually encourages members to practise in thinly capitalised firms.

${ }^{35}$ Robert B. Thompson, "Unpacking Limited Liability: Direct and Vicarious Liability of Corporate Participants for Torts of the Enterprise" (1994) 47 Vanderbilt Law Reviem 1, 14.

${ }^{36}$ Katie Fairbank and Terry Maxon, "How Jenkens Lost its Way: As Law Firm Dissolves, Leaders Have No Doubt Tax Scheme to Blame" Dallas Morning Nems, 1 April 2007, www.dallasnews.com/sharedcontent/dws/ news/localnews/stories/DN-jenkens 01ent.ART.North.Edition1.4426a58.html, accessed 15 December 2008.

${ }^{37}$ For example, one shelter used a complicated strategy of offsetting currency options - one to buy one currency and the other to sell another currency - to create a paper loss for the taxpayer. Interests in this shelter were marketed to clients with a tax shelter opinion stating that the scheme was "more likely than not" legal under the tax code. Ibid.

38 Ibid. Mr Daugerdas reportedly received $\$ 93$ million in fees from 1999 to 2003.

39 Ibid.

${ }^{40}$ Ibid.

${ }^{41}$ Thompson, supra n. 35, 11-12. 
Requiring that limited liability firms maintain adequate levels of insurance can help to minimise the risk of asset insufficiency. Unfortunately, the majority of US jurisdictions do not require that firms maintain adequate levels of insurance or assets on a per lawyer basis.

Moreover, no legislation in the US addresses the other detrimental consequences of eliminating unlimited liability, ${ }^{42}$ including the risk that firm members will shirk responsibility for the conduct of other firm members. ${ }^{43}$ By contrast, the Australian approach discussed in the next section promotes collective responsibility by requiring various safeguards and measures to ensure that all firm members act in accordance with their professional obligations.

\section{Pubic Protection and Incorporated Law Practice in Australia}

In 2000, the Australian state of New South Wales adopted the Legal Profession Amendment (Incorporated Legal Practices) Act 2000 (ILP Act). This Act enables providers of legal services to incorporate by registering a company under Australia's federal company law. Upon registration, firms are governed by the provisions of the ILP Act, as well as the nationwide corporations legislation.

An examination of the legislative history of the ILP Act reveals that the legislators and various stakeholders considered organisational dynamics and consumer protection in formulating an approach that balances lawyer interests with public interests.

Specifically, the ILP Act imposes a number of requirements that relate to management and practice safeguards. First, the ILP must appoint at least one "legal practitioner director" who is generally responsible for the management of legal services provided by the ILP. ${ }^{44}$ The Act specifically outlines the credentials and obligations of the legal practitioner director. In describing these obligations, Steven Mark, the chief regulator in New South Wales, notes that the "first oversight obligation of all solicitors working for an ILP is to comply with a solicitor's ethics and professional responsibility". ${ }^{45}$ The ILP Act imposes a number of other responsibilities, including those relating to accounting for clients' money and maintenance of professional liability insurance policies. ${ }^{46}$ Under the Act, failure to fulfil the statutorily imposed responsibilities constitutes "professional misconduct" that will be prosecuted by regulatory authorities.

Furthermore, the ILP Act states that it is "professional misconduct" if the legal practitioner director does not ensure that:

(a) Appropriate management systems are implemented and maintained to enable the provision of legal services in accordance with the professional obligations of legal practitioners and other obligations imposed by or under this Act; and

${ }^{42}$ In the US, state disciplinary rules based on American Bar Association Rule 5.1 require that a firm partner shall make reasonable efforts to ensure that the firm has in effect measures giving reasonable assurance that all lawyers in the firm conform to the Rules of Professional Conduct. Model Rules of Professional Conduct, R. 5.1(a) (2008).

${ }^{43}$ David Deary, the lead attorney for the plaintiff class' suit against Jenkens \& Gilchrist, stated that "[c]ertain people ... in the management positions turned a blind eye to what was going on . . . the Dallas and Austin offices, for example, really didn't know what was going on." Fairbank and Maxon, supra n. 36.

${ }^{44}$ Steven Mark and Georgina Cowdroy, "Incorporated Legal Practice-A New Era in the Provision of Legal Services in the State of New South Wales" (2004) 22 Penn State International Law Reviem 671, 681.

${ }^{45} \mathrm{Ibid}, 682$.

${ }^{46}$ For more commentary on the various obligations, see ibid, 684-6. 
(b) Any conduct of another director of the practice that has resulted or is likely to result in a contravention of those obligations is reported to the Law Society Council promptly after the legal practitioner director becomes aware of it; and

(c) Any professional misconduct of a legal practitioner employed by the practice to provide legal services is reported to the Law Society Council promptly after the solicitor director becomes aware of it; and

(d) All reasonable action available to the legal practitioner director is taken to deal with any professional misconduct or unsatisfactory professional conduct of a solicitor so employed by the practice. ${ }^{47}$

J.W. Shaw, New South Wales Attorney-General at the time the legislation was passed, described how improved management structures promise to improve the delivery of legal services:

Incorporation will lead to more transparent management structures in legal firms, because the requirements of the Corporations Law [sic]. Within a corporate structure, the accountability of individuals for the management of the practice will be enhanced and this is likely to lead to better delineation of responsibilities within firms and to more efficient service provision. ${ }^{48}$

Because the ILP Act does not define "appropriate management systems", representatives from various organisations collaborated in an effort to determine what objectives should be met to help ascertain whether an ILP has "appropriate management systems" in place. ${ }^{49}$ The approach devised is an "education toward compliance" strategy in which ILPs must demonstrate that they have procedures in place evidencing compliance with "ten objectives of sound legal practice". ${ }^{50}$

To assess an ILP's performance with respect to these objectives, the regulatory scheme provides for self-assessment audits conducted by firms themselves. The self-assessment requires that the legal practitioner director rate the ILP's compliance with each of the 10 objectives. When a firm's self-assessment indicates that the firm is "Non-Compliant" or "Partially-Compliant", a representative from the regulatory body will conduct an on-site, one-day review of the legal practice. Following the review and related interviews, the regulator will draft a review report discussing the firm's management systems and ways in which management practices can be improved. Thereafter, follow-up reviews are conducted. ${ }^{51}$ This entire process gives the firm the opportunity to first engage in self-examination of management practices and then obtain guidance from regulators prepared to assist the firm.

Following the NSW lead, other Australian states and territories have enacted similar legislation. These other jurisdictions have also implemented self-audit and external audit procedures. In their contribution to this special issue, John Briton, the Legal Services

47 Mark and Cowdroy, supra n. 44, 686.

48 J.W. Shaw, "Speech given at NSW Young Lawyers Annual Conference on 6 Nov. 1999", www.lawsociety. com.au/page.asp? PartID=499, accessed 29 November 2008.

${ }^{49}$ Mark and Cowdroy, supra n. 44, 689-90, noting that the New South Wales Officer of the Legal Services Commission, the New South Wales Law Society, the NSW College of Law and LawCover, the professional indemnity insurance body worked together to determined the objectives for gauging "appropriate management systems".

50 John Briton and Scott McLean, "Incorporated Legal Practices: Dragging the Regulation of the Legal Profession into the Modern Era" (Speech at the Third International Legal Ethics Conference, Gold Coast, Australia, 13-16 July 2008), www.Isc.qld.gov.au/speeches/Legal_Ethics_JWB_SAM.pdf, [10], accessed 15 December 2008.

51 Mark and Cowdroy, supra n. 44, 691-2. 
Commissioner for Queensland, and Scott McLean, the Principal Legal Officer and Practice Compliance Manager for the Queensland Legal Services Commission, thoughtfully describe how the new framework of regulating professional standards in ILPs is more effective than the traditional complaint-driven regimes for monitoring and enforcing standards of conduct, and also outline the features of an effective program of external audits. ${ }^{52}$

A recent multi-faceted study actually reveals a connection between the new regulatory regime for ILPs and the number of complaints filed against firms that had undertaken selfassessment. Using data relating to 631 New South Wales ILPs that had completed the selfassessment process, Christine Parker of the Melbourne Law School, along with Tahlia Gordon, Research Officer, with the Office of Legal Services Commissioner for New South Wales, and Steve Mark, the New South Wales Legal Services Commissioner, studied various effects of the ILPs completing the self-assessment process. ${ }^{53}$ In attempting to evaluate whether the "education towards compliance", "management-based" approach makes a difference, the researchers tackled the following hypotheses:

1. Incorporated firms that have engaged the self-assessment process are better managed, meet their ethical conduct obligations better, and prompt less client and other complaints to the Legal Services Commission than before the firms completed the self-assessment process.

2. ILPs that have completed the self-assessment are better managed and engage in more ethical conduct than those unincorporated firms that have not completed the self-assessment.

3. ILPs that have rated themselves more highly on their management systems are better managed, engage in more ethical conduct, and have less client complaints [sic] than those who rate themselves more lowly. ${ }^{54}$

To test these hypotheses, the researchers used complaint rates as indicators of good management and ethical behaviour in firms. This reliance is based on the fact that the objectives and appropriate management systems requirements were designed explicitly to address the types of conduct that lead to complaints.

Notably, the statistics on complaints reveal that the complaints rate for self-assessed ILPs drops by two-thirds after the firms have completed their initial self-assessment. In testing the second hypothesis, the researchers found that ILPs that completed the self-assessment process have significantly lower complaints rates (about one-third of the number of complaints) than non-incorporated firms. With respect to the third hypothesis, there was little evidence that the number of complaints was affected by different levels of self-assessment implementation of appropriate management systems. ${ }^{55}$ Based on these findings, the researchers conclude:

Overall our study shows compelling evidence that the Australian legislative approach requiring ILPs to implement appropriate management systems combined with the . . . innovative

52 Briton and McLean, supra n. 50, 6-17.

53 Christine Parker, Steve Mark, and Tahlia Gordon, "Research Report, Assessing the Impact of ManagementBased Regulation on NSW Incorporated Legal Practice” (25 September 2008), www.lawlink.nsw.gov.au/lawlink/ olsc/ll_olsc.nsf/vwFiles/Research_Report_ILPs.pdf/Sfile/Research_Report_ILPs.pdf, accessed 15 December 2008.

54 Ibid, [3].

55 Ibid, [38], [43], [46]-[48]. 
self-assessment regime for encouraging firms to actually put this into practice makes a big difference as to how well these firms are managed and to lawyer behavior as judged by complaints rates. ${ }^{56}$

Recognising the positive impact of self-assessment, some have suggested that the "appropriate management systems" requirement should eventually apply to all legal practices, not just those that are incorporated. ${ }^{57}$

\section{Conclusion}

The saga of the limited liability movement reveals that the US regulatory regime for limited liability firms leaves gaping holes in the blanket protecting consumers. Many states in the US do not require that limited liability firms maintain any or meaningful levels of professional liability insurance. Because the limited liability structure eliminates the unlimited liability of all firm owners, this poses the risk of asset insufficiency to pay damages to injured persons. ${ }^{58}$ Even in those states where insurance is required, the regulatory scheme in the US does not address organisational dynamics and the disincentives to lawyers serving as managers, supervisors, and mentors.

By contrast, all Australian firms must carry professional liability insurance. The Australian regulatory regime also focuses on fortifying the ethical infrastructure of firms by requiring that ILPs implement appropriate management systems. Furthermore, the self-assessment and audit approach to management-based regulation creates a vehicle for regulators and firm managers to consult one another in an effort to improve the delivery of legal services. As revealed by the study findings discussed above, the self-assessment process completed by ILPs has already resulted in a dramatic reduction in the number of consumer complaints.

In the US, it is doubtful that legislators or state high courts will mandate additional regulation for limited liability firms. US regulators of the legal profession will likely continue their complaints-based approach to disciplining attorneys. At some point in the future, the interest in a more management-based approach may evolve if US firms push for changes to allow practice in multi-disciplinary practices. At that time, concerns about lawyers practising in multidisciplinary partnership may be addressed if any proposal for change included features of the Australian regulatory regime for ILPs. Specifically, practice in a multi-disciplinary firm would be allowed provided that the firm implemented appropriate management systems.

Even if the Australian approach is not adopted as a formal regulatory regime in the US, lawyers interested in merging good ethics with good business should seriously consider the data that indicate that self-examination of firm practices and policies raises the ethical bar, protecting consumers while lowering lawyers' liability exposure. Although firm lawyers in the US may resist any proposal that requires regulatory audits of firm practices, empirical findings help lawyers to appreciate that they should engage in self-examinations as a matter of risk management and professionalism. 